\title{
Biomedical Importance of Momordica Cochinchinensis (Gac) Fruit and Future Applications
}

\author{
Tien Huynh*1, Dao Nguyen ${ }^{2}$ and Minh Nguyen ${ }^{3,4}$ \\ ${ }^{1}$ School of Sciences, RMIT University, Australia \\ ${ }^{2}$ Tay Nguyen University, Vietnam \\ ${ }^{3}$ School of Environmental and Life Sciences, University Drive, Australia \\ ${ }^{4}$ School of Science and Health, Western Sydney University, Australia
}

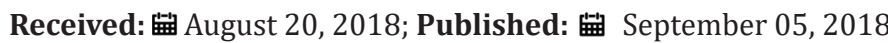

*Corresponding author: Tien Huynh, School of Sciences, RMIT University, Australia

\begin{abstract}
Momordica cochinchinensis is a cucurbit that has long been neglected resulting in its widespread loss from wild habitats. Scientific research has highlighted its biomedical potential as a superior source of nutrition and medicine, with potent activity against various ailments including cancers This mini review focuses on recent advances and showcases the bioactive compounds to scientifically validate its usefulness and inspire future applications.
\end{abstract}

\section{Bioactive Compounds}

Momordica cochinchinensis (Lour.) Spreng is geographically restricted to tropical climates predominantly in Southeast Asia with wild populations both genetically and morphologically diverse Wimalasiri et al. [1]. Vernacular names throughout Australasia to Europe suggest its historical significance and widespread occurrence Lim but its importance was often downgraded by the majority of the community as a common and inexpensive food crop. Scientific validation has highlighted and elevated the importance of the fruit and has rejuvenated the crop for future developments locally and internationally. The aril of $M$. cochinchinensis contains the highest levels of nutritionally important carotenoids of all known fruits and vegetables, with more than 150 and 200 times the level of lycopene and $\beta$-carotene than that found in tomatoes and carrots, respectively Gul et al. [2]; Javanmardi \& Kubota Vuong and King, Wimalasiri et al.

These carotenoids produce the vibrant colours (red for lycopene and orange for $\beta$-carotene) responsible for antioxidation Tuyen et al. and are ideal candidates as food additives. M. cochinchinensis is well placed to meet increasing consumer demands for naturally sourced red and orange pigments in foods and beverages with artificial coloring associated with hyper activeness Sigurdson et al. [3] toxicity and allergenic Ferreira [4] concerns. The aril also contains proteins Tien and biomolecules Wimalasiri et al. [5] active against skin, breast, kidney and colon cancer cells. Cancer mortality rates have declined due to increased early diagnosis and treatment
Cronin et al. [6] but current treatments using chemotherapy and radiotherapy can have adverse side effects. This is a golden opportunity to explore adjunctive therapies to provide the body with more ammunition against cancers and fast-track the healing process by targeting apoptotic cancer cell death pathways since it bypasses inflammation and is less damaging on surrounding host cells Nagata.

There is still too much unknown and further research is needed to optimize the potentials of the aril. The seed has a more potent and diverse range of bioactive compounds including anticancer us Chan et al. Zhao et al. [7] antiviral Oyuntsetseg et al. [8] antimicrobial Desbois and Smith trypsin inhibition Huang et al. [9] antioxidation and immune enhancing Wong et al. properties Additionally, seeds contain small potent proteins capable of neurogenesis Mazzio et al. [10-15] pertinent to our aging population and associated age-related neurodegenerative diseases. The seeds also produce cyclotides, a versatile and highly stable circular protein Craik et al. synthesized by the plant for defense that has inspired novel drug delivery systems and future frameworks for complex drug designs Weidmann and Craik as biomedicines. The use of these thermally, chemically and enzymatically stable cyclotides Craik et al. could also be commercialized as cost efficient and eco-friendly bio insecticides.

With the increasing demand for organic agriculture Muller et al. and rising concerns for our pollinators Evans et al., plant- 
derived compounds could be the answer to a pesticide-free farming system. Considering that the seed constitutes similar proportions as the aril by weight $(\sim 17 \%)$ but is often discarded as waste, this is an underutilized resource that warrants further investigation. Other components of the fruit that is often discarded as waste is the pulp and peel that constitutes up to $70 \%$ of the fruit. The pulp contains significant concentrations of apigenin Kubola [16] that has pharmacological potential against oxidative stress, inflammation, toxins and cancers, Ali et al. [17-20] The peel has the highest levels of lutein and zeaxanthin essential for eye health and protection against light-induced oxidative stress leading to macular degeneration Abdel-Aal. The levels of lutein and zeaxanthin Kubola and Siriamornpun, Kha et al. [21] far surpassed its nearest rivals in watermelon and parsley by magnitudes of $10 \times 3$ to $10 \times 6$ Abdel-Aal. Other folklores include the benefits of utilizing the Gac leaves and roots indicate potential for more evidence-based research.

\section{Conclusion}

Development of these natural compounds from $M$. cochinchinensis holds much promise in our community as a biomedicine and biomolecule for the future. The growing use of Gac products in health, cosmetics and personal care suggest new ways to deliver nutrients and these bioactives. The fruit sounds too good to be true but has been quoted as 'the fruit from heaven' by many rural communities and farmers. Perhaps it's time we gave it the attention it deserves.

\section{References}

1. Abdel Aal ES M, H Akhtar, K Zaheer, R Ali (2013) Dietary Sources of Lutein and Zeaxanthin Carotenoids and Their Role in Eye Health. Nutrients 5(4): 1169-1185.

2. Ali F, Rahul, F Naz, S Jyoti, YH Siddique (2017) Health functionality of apigenin: A review. Int J Food Prop 20(6): 1197-1238.

3. Chan LY, CK L Wang, JM Major, KP Greenwood, RJ Lewis, et al. (2009) Isolation and characterization of peptides from Momordica cochinchinensis seeds. J Nat Prod 72(8): 1453-1458.

4. Craik DJ, M Cemazar, CK Wang NL Daly (2006) The cyclotide family of circular miniproteins: nature's combinatorial peptide template. Biopolymers 84(3): 250-266.

5. Cronin KA, AJ Lake, S Scott, RL Sherman, A M Noone, et al. (201) Annual Report to the Nation on the Status of Cancer, part I: National cancer statistics. Cancer 124(13): 2785-2800.

6. Desbois AP, VJ Smith (2010) Antibacterial free fatty acids: activities, mechanisms of action and biotechnological potential. Appl Microbiol Biotechnol 85(6): 1629-1642.

7. Evans AN, JE M Llanos, WE Kunin, S E F Evison (2018) Indirect effects of agricultural pesticide use on parasite prevalence in wild pollinators. Agric Ecosyst Environ 258: 40-48.
8. Ferreira IC (2018) c 9es Journees Scientifiques Internationales sur la Valorisation des Bioressources.

9. Gul K, A Tak, AK Singh, P Singh, Y Basharat, AA Wani (2015) Chemistry, encapsulation, and health benefits of $\beta$-carotene - A review. Cogent Food Agr 1(1): 1-12.

10. Huang B, TB Ng, WP Fong, CC Wan, HW Yeung (1999) Isolation of a trypsin inhibitor with deletion of $\mathrm{N}$-terminal pentapeptide from the seeds of Momordica cochinchinensis, the Chinese drug mubiezhi. Int J Biochem Cell Biol 31(6): 707-715.

11. Javanmardi J, C Kubota (2006) Variation of lycopene, antioxidant activity, total soluble solids and weight loss of tomato during postharvest storage. Postharvest Biol Tech 41(2): 151-155.

12. Kha TC, MH Nguyen, PD Roach, SE Parks, C Stathopoulos (2013) Gac fruit: nutrient and phytochemical composition, and options for processing. Food Rev INT 29(1): 92-106.

13. Kubola J, S Siriamornpun (2011) Phytochemicals and antioxidant activity of different fruit fractions (peel, pulp, aril and seed) of Thai gac (Momordica cochinchinensis Spreng). Food Chem 127(3): 1138-1145.

14. Mazzio E, R Badisa, S Eyunni, S Ablordeppey, B George, et al. (2018) Bioactivity-Guided Isolation of Neuritogenic Factor from the Seeds of the Gac Plant (Momordica cochinchinensis). Evid Based Complement Alternat Med.

15. Muller A, C Schader, NEl Hage Scialabba, J Bruggemann, A Isensee, et al. (2017) Strategies for feeding the world more sustainably with organic agriculture. Nat Commun 8(1): 1290.

16. Nagata S (2018) Apoptosis and Clearance of Apoptotic Cells. Annu Rev Immunol 36(1): 489-517.

17. Oyuntsetseg N, MA Khasnatinov, P Molor Erdene, J Oyunbileg, AV Liapunov, et al. (2014) Evaluation of direct antiviral activity of the Deva5 herb formulation and extracts of five Asian plants against influenza A virus H3N8. BBMC Complement Altern Med 14(1): 235.

18. Sigurdson GT, P Tang, MM Giusti (2017) Natural Colorants: Food Colorants from Natural Sources. Annu Rev Food Sci Technol 8(1): 261280.

19. Tien PG, F Kayama, F Konishi, H Tamemoto, K Kasono, et al (2005) Inhibition of tumor growth and angiogenesis by water extract of Gac fruit (Momordica cochinchinensis Spreng). Int J Oncol 26(4): 881-889.

20. Weidmann J, DJ Craik (2016) Discovery, structure, function, and applications of cyclotides: circular proteins from plants. J Exp Bot 67(16): 4801-4812.

21. Wimalasiri D, T Piva, T Huynh (2016) Diversity in nutrition and bioactivity of Momordica cochinchinensis. Int J Adv Sci Eng Inf Technol 6(3): 378-380.

22. Wong FC, AL Yong, EPS Ting, SC Khoo, HC Ong, et al. (2014) Antioxidant, metal chelating, anti-glucosidase activities and phytochemical analysis of selected tropical medicinal plants. Iranian J Pharm Res 13(4): 14091415.

23. Zhao L, G Sun, L Han, L Liu, F Ren, et al. (2016) p-Hydroxycinnamaldehyde Induces B16-F1 Melanoma Cell Differentiation via the RhoA-MAPK Signaling Pathway. Cell Physiol Biochem 38(6): 2247-2260. 
ISSN: 2574-1241

DOI: $10.26717 /$ BJSTR.2018.08.001693

Tien Huynh. Biomed J Sci \& Tech Res

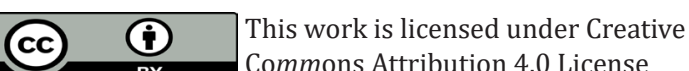

Submission Link: https://biomedres.us/submit-manuscript.php

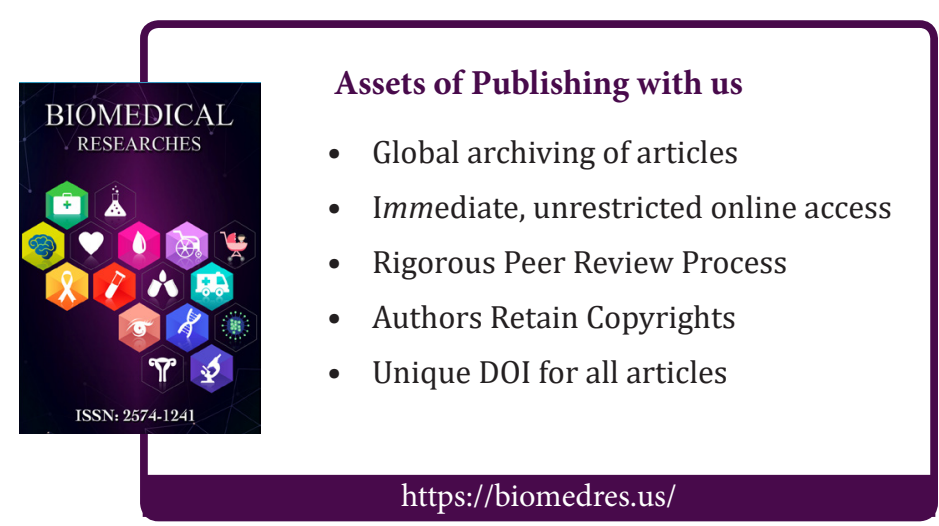

